\title{
Research On The Relationship Among Over-investment, Audit Quality And Corporate Risk Of Listed Companies Based On Big Data
}

\section{-Based on the Empirical data of listed companies in China}

\author{
Zhao Tiantian ${ }^{1}$ \\ ${ }^{1}$ School of Economics and Management Beijing Jiaotong University Beijing, China
}

\begin{abstract}
At present, most companies in China have the problem of inefficient investment, and inefficient investment will bring certain business risks to the enterprise. In addition, the quality of external auditing, as a part of the company's external governance mechanism, also has an impact on the investment efficiency of listed companies and corporate risks. Based on big data research, this paper selects data samples of Chinese A-share listed companies from 2014 to 2018, and uses STATA to process the data to study the impact of overinvestment on corporate risks. At the same time, considering the influence of external independent audit, this paper try to verify whether audit quality will have a negative moderating effect. In addition, this article combines China's system to study whether overinvestment and audit quality have different impacts on corporate risks for companies with different property rights. Through the use of big data analysis and computer data processing analysis, this paper finds that audit quality has a restraining and regulating effect on corporate risks caused by corporate over-investment, and this effect has certain differences in companies with different property rights.
\end{abstract}

\section{Introduction}

Investment activities are one of the important activities in the financial management of modern enterprises. Investment activities are not only related to the financial risks and operating risks of the enterprise, but also critical to the value and development of the enterprise. China's macro-control and internal adjustments of enterprises have given enterprises more freedom of investment autonomy, however, what follows is that many enterprises have inefficient investment problems, and this may bring a series of operating risks. In addition, with the development of productivity and the continuous progress of society, the importance of company stakeholders to the company's disclosure of information and the requirements for the quality of accounting information are also increasing. As one of the company's external governance factors, auditing can alleviate the problem of excessive investment caused by agency problems, thereby reducing corporate risks.

This article uses big data to study how over-investment and audit quality of listed companies affect corporate business risks, to a certain extent, which can deepen the depth of related theoretical research on corporate inefficient investment and corporate risk. At present, most of the existing literature studies the relationship between over-investment and corporate risk, but there are few studies on the impact of audit quality on the two. Aiming at China's capital market environment, this paper puts the degree of overinvestment of listed companies, audit quality and corporate risk in the same framework to conduct big data empirical research, and provides a new perspective for the study of the relationship among the three.

\section{Theoretical Analysis And Research Hypothesis}

Through Xie Zhong's (2018) research, it is found that in order to pursue the scale effect, the management of some companies will be willing to accept investment projects with a negative net present value, leading to excessive investment in the company [1]. Because excessive investment has deviated from the company's optimal operating activities, it will inevitably have an adverse impact on the company's development, which will lead to the risk of stock price collapse (Jin, 2006) [2]. In general, excessive investment deviates from the company's optimal operating activities, reduces the company's value to a certain extent and harms the interests of shareholders, and is not conducive to the company's long-term development. Therefore, in the process of excessive investment, negative information such as shortage of funds, slow project progress, and impaired business performance will inevitably be generated. The specific impact is shown in 
Figure 1. Therefore, this article proposes the following hypothesis $\mathrm{H} 1$ to be tested:

H1: Under the same conditions as other conditions, over-investment aggravates the company's business risk, that is, the deeper the company's over-investment, the higher the corporate risk.

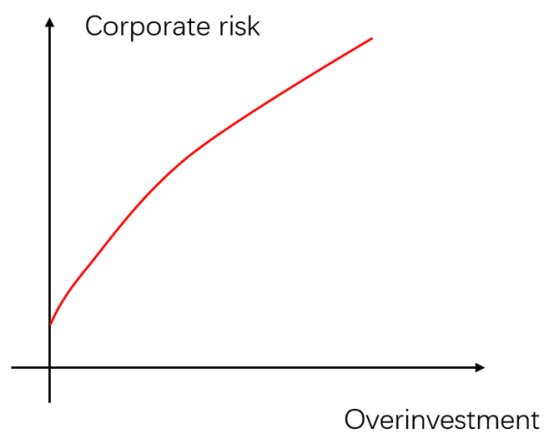

Fig 1. Diagram of the relationship between overinvestment and corporate risk

For external auditing, studies have found that the quality of external auditing has an impact on corporate risks. First of all, high-quality external audit is conducive to restraining management's behavior, reducing the degree of asymmetry of company information, ensuring the authenticity and reliability of financial reports, providing external investors with higher-quality accounting information, and giving play to the supervisory role of external auditing. Jiang Xuanyu and Yi Zhihong (2013) found that the industry expertise possessed by accounting firms is negatively correlated with corporate risk, as shown in Figure 2 [3]. At the same time, high external audit quality can effectively reduce the company's information asymmetry. Because the company's management has an inherent information advantage, in order to weaken this advantage, external investors need to use external auditing as a channel to understand the company's operating status, learn about the company's unfavorable information, and reduce the possibility of investment errors.

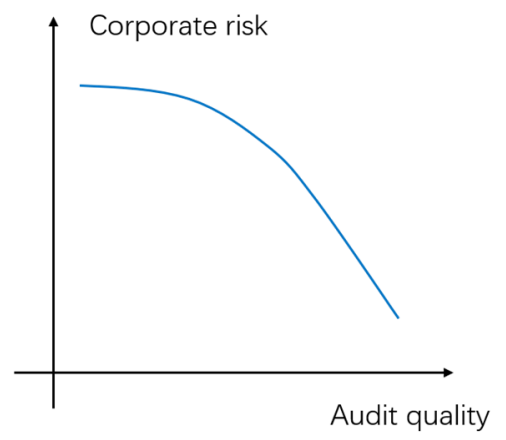

Fig 2. Schematic diagram of the relationship between audit quality and corporate risk

Chu Yiyun et al. (2017) found that the audited financial reports of the Big Four accounting firms can objectively and fairly reflect the company's operating results and financial status, which can improve the company's information transparency and reduce the company's information asymmetry [4]. Therefore, external investors can have a more comprehensive and true understanding of the status quo of the company's operations, so that they can make more rational investments. When the amount of negative information generated by the company due to excessive investment remains unchanged, the improvement of external audit quality can help reduce the degree of information asymmetry and reduce business risks. The relationship between the three is shown in Figure 3. Therefore, this article proposes the following hypothesis $\mathrm{H} 2$ to be tested:

$\mathrm{H} 2$ : Under the circumstance that other conditions remain unchanged, a high-quality external audit can restrain the impact of excessive investment on corporate risks.

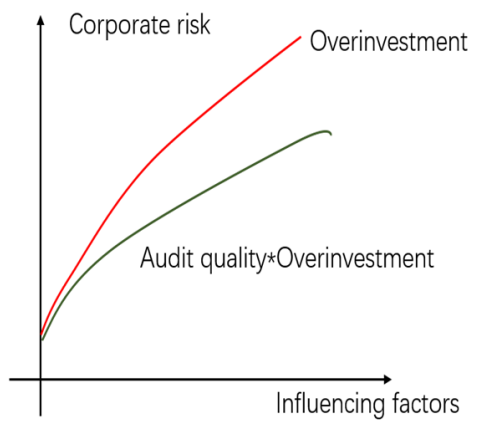

Fig 3. The joint effect of over-investment and audit quality on corporate risk

\section{Research Design}

\subsection{Data sample}

This article selects the five-year data of Chinese A-share listed companies from 2014 to 2018 . The data is mainly from the CSMAR database, and is processed as follows: 1 . exclude samples with missing data and abnormalities; 2 . exclude samples from the financial industry; 3 . exclude ST listed companies; 4. 1\% level tailing treatment. After screening, 5062 company annual sample data are finally obtained.

\subsection{Variable measure}

\subsubsection{Corporate risk}

This article draws on Li Wengui and Yu Minggui's (2012) method of measuring corporate risk, and divides profit before interest and taxes by total assets to measure the return on assets (ROA) of a company, and then adjusts the annual ROA according to the industry average to obtain ROA_adj. Finally, calculate the rolling standard deviation of ROA_adj between the current year and the following two years of the enterprise for a total of three years (for ease of presentation, multiply the result by 100) [5].

$$
\begin{gathered}
\text { Risk }_{i}=100 \times \sqrt{\left.\frac{1}{2} \sum_{t=1}^{3}\left(R O A_{a d j}-\frac{1}{3} \sum_{t=1}^{3} R_{i, t} O A_{a d j}\right)_{i, t}\right)^{2}} \\
\operatorname{ROA}_{\text {adj }_{i, t}}=\frac{\text { EBIT }_{i, t}}{\text { Asset }_{i, t}}-\frac{1}{X_{t}} \sum_{k=1}^{X} \frac{\text { EBIT }_{k, t}}{\text { Asset }_{k, t}}
\end{gathered}
$$


Among them, $\mathrm{i}$ represents the company, $\mathrm{t}$ represents the year, and $\mathrm{X}$ represents the number of listed companies.

\subsubsection{Overinvestment}

This paper uses Richardson's model (2006) to measure the model of inefficient investment to measure the overinvestment of enterprises [6]. The idea of this model is to use the difference between the actual investment level reflected in the company's accounting information and the model's estimated capital investment level to determine the company's inefficient investment. If the residual is positive, it represents the company's over-investment problem. The model is as follows:

$$
\begin{aligned}
& \text { Inv }=\beta_{0}+\beta_{1} \text { Inv }_{t-1}+\beta_{2} \text { Cash }_{t-1}+\beta_{3} \text { Size }_{t-1}+ \\
& \beta_{4} \text { Lev }_{t-1}+\beta_{5} \text { Tobin }_{t-1}+\beta_{6} \text { Ret }_{t-1}+\beta_{7} \text { Age }_{t-1}+ \\
& \sum \text { Year }+\sum \text { Industry }+\varepsilon
\end{aligned}
$$

The definition of variables in the model are shown in the following table:

Table1. Variable Definitions

\begin{tabular}{|l|l|}
\hline \multicolumn{1}{|c|}{ Variable Symbol } & \multicolumn{1}{c|}{ Variable Definitions } \\
\hline Inv & Total company investment \\
\hline Cash & Cash holdings \\
\hline Size & Company Size \\
\hline Lev & Financial leverage \\
\hline Tobin Q & Asset market value / book value \\
\hline Ret & Annual return of company stock \\
\hline Age & Company age \\
\hline Industry & Industry dummy variables \\
\hline Year & Annual dummy variable \\
\hline
\end{tabular}

\subsubsection{Audit quality}

Discretionary accruals as a proxy variable to measure audit quality has been widely recognized by academics (Zhang Hongliang, Wen Ting, 2016) [7]. For this reason, the absolute value of discretionary accruals was selected as a proxy variable for audit quality. Because the Jones model (1991) can measure the discretionary accruals more effectively [8], this paper uses the model regression to derive the discretionary accruals profit DA as the proxy variable for the accrual earnings management. The specific model is as follows:

$$
\frac{\text { Accruals }_{t}}{A_{t-1}}=\alpha_{0}+\frac{\alpha_{1}}{A_{t-1}}+\alpha_{2} \frac{\Delta S_{t}}{A_{t-1}}+\alpha_{3} \frac{P P E_{t}}{A_{t-1}}+\varepsilon_{t}
$$

Accruals $_{t}=$ net profit in year t-operation cash flow in year $\mathrm{t}, A_{t-1}=$ total assets in year $\mathrm{t}-1, \Delta S_{t}=$ compared with the previous year, the main business income changes this year, PPEt $=$ net fixed assets in year t. The residuals derived from the regression of this model are the manipulative accrued profit DA, which is used to measure the audit quality.

\subsubsection{Control variables}

This paper draws on the research of Tang Hua (2019) to

\begin{tabular}{|c|c|c|}
\hline & $\begin{array}{l}\text { Variable } \\
\text { symbol }\end{array}$ & Variable definitions \\
\hline $\begin{array}{c}\text { Explanatory } \\
\text { variable }\end{array}$ & OverInv & Richardson model residuals \\
\hline Moderator & DA & $\begin{array}{c}\text { Jones model corresponds to the } \\
\text { absolute value of surplus } \\
\text { manipulation }\end{array}$ \\
\hline $\begin{array}{l}\text { Explained } \\
\text { variable }\end{array}$ & Risk & Model (1) calculation results \\
\hline \multirow{10}{*}{$\begin{array}{l}\text { Control } \\
\text { variable }\end{array}$} & Big4 & $\begin{array}{l}\text { The auditor takes } 1 \text { for the "Big } \\
\text { Four", otherwise } 0\end{array}$ \\
\hline & PPE & Fixed assets/total assets \\
\hline & Size & $\begin{array}{l}\text { Natural log of total assets at the end } \\
\text { of the period }\end{array}$ \\
\hline & Growth & Growth rate of total assets \\
\hline & FCF & $\begin{array}{l}\text { Net cash flow from operating } \\
\text { activities / total assets }\end{array}$ \\
\hline & Lev & $\begin{array}{l}\text { Total liabilities at the end of the } \\
\text { period / total assets at the end of } \\
\text { the period }\end{array}$ \\
\hline & $\mathrm{Mh}$ & Management shareholding ratio \\
\hline & SOE & $\begin{array}{c}\text { State-owned enterprises take } 1 \text {, } \\
\text { otherwise } 0\end{array}$ \\
\hline & Industry & Industry dummy variables \\
\hline & Year & Annual dummy variable \\
\hline
\end{tabular}
select control variables [9].

The main variables of this article are as follows:

Table2. Main Variables Of This Articles

\subsection{Empirical test model construction}

According to the hypothesis, establish Model 5 to verify the impact of stock overinvestment on corporate risks:

$$
\begin{aligned}
& \text { Risk }_{t}=\beta_{0}+\beta_{1} \text { OverInv }_{t}+\sum \delta_{t} \text { control }_{t}+ \\
& \sum \text { Year }+\sum \text { Industry }_{+} \theta_{t}
\end{aligned}
$$

According to the theoretical logic of the hypothesis, $\beta 1$ is positive in the expected model (5).

According to the hypothesis, establish Model 6 to verify the influence of audit quality on the moderating effect of stock overinvestment and corporate risk:

$$
\begin{aligned}
& \text { Risk }_{t}=\beta_{0}+\beta_{1} \text { OverInv }_{t}+\beta_{2} \text { DA }_{t}+\beta_{3} \text { OverInv }_{t} \\
& D A_{t}+\sum \delta_{t} \text { control }_{t}+\sum \text { Year }+\sum \text { Industry }+\theta_{t}
\end{aligned}
$$

According to the theoretical logic of the hypothesis, $\beta 1$ is positive and $\beta 3$ is negative in the expected model (6).

\section{Empirical Testing And Empirical Results}

\subsection{Regression test}

According to the model (5) and model (6), the sample is subjected to regression analysis, and the results obtained are shown in the following table: 
Table3. Over-investment, audit quality and corporate risk regression results

\begin{tabular}{|c|c|c|c|c|}
\hline Variables & Full Sample & Full Sample & $\begin{array}{l}\text { State-owned } \\
\text { Enterprise }\end{array}$ & Private Enterprise \\
\hline OverInv & $2.0016^{*}$ & $0.0104 * *$ & $0.0145^{* *}$ & 0.0026 \\
\hline$D A$ & & $-0.0197^{* * *}$ & $-0.0285^{* *}$ & -0.0049 \\
\hline OverInv $* D A$ & & $-0.0323 * *$ & $-0.0407 *$ & -0.0098 \\
\hline Lev & 0.1567 & $-0.0105^{* *}$ & $-0.0148 * *$ & -0.0018 \\
\hline Size & $-0.2259 * * *$ & $-0.0052^{* * *}$ & $-0.0058^{* * *}$ & $-0.0040^{* * *}$ \\
\hline$F C F$ & $-0.5207^{*}$ & $0.0251 * *$ & 0.0209 & $0.0298^{* *}$ \\
\hline Growth & $0.5877^{* *}$ & $0.0073^{* * *}$ & $0.0069^{* * *}$ & $0.0082 * *$ \\
\hline PPE & $-6.2133 * *$ & -0.0127 & -0.0043 & -0.0234 \\
\hline SOE & $0.5265^{* * *}$ & $0.0094 * * *$ & & \\
\hline Big4 & $0.0160^{*}$ & $0.0064 * *$ & $0.0089 * *$ & 0.0032 \\
\hline$M h$ & 0.0028 & $0.0000^{* * *}$ & $0.0000^{* * *}$ & 0.0001 \\
\hline cons & $10.2094 * * *$ & $0.173^{* * *}$ & $0.113^{* * *}$ & $0.0939 * * *$ \\
\hline Industry & \multicolumn{4}{|c|}{ Control } \\
\hline Year & \multicolumn{4}{|c|}{ Control } \\
\hline$N$ & 4302 & 5062 & 3289 & 1773 \\
\hline$R^{2}$ & 0.070 & 0.081 & 0.062 & 0.082 \\
\hline$F$ & 11.18 & 18.824 & 103.583 & 4.721 \\
\hline
\end{tabular}

In the full sample, over-investment has a significant positive impact on corporate risk at the level of $10 \%$, indicating that over-investment will indeed increase corporate operating risks, which is consistent with the assumption of H1. This is mainly because the company's management's excessive investment deviates from the company's optimal operating activities, which is not conducive to the company's long-term development and generates certain operating risks. In addition, after adding the crossover item of audit quality and over-investment, the coefficient is -0.032 , and it is significant at the $5 \%$ level, indicating that audit quality can negatively regulate the corporate risk caused by over-investment, thus confirming the hypothesis 2 . In this regard, this article believes that, as one of the company's external supervision mechanisms, external auditing can effectively restrain the self-interested behavior of the company's management in a timely manner and restrain the impact of excessive investment on corporate risks.

In addition, this article regressed model (6) according to the nature of property rights. From the results, the adjustment effect of audit quality is more obvious in stateowned enterprises.

\subsection{Robustness test}

Use the method of substitution variables to test the robustness:

- The rolling standard deviation of ROA for three consecutive years is selected to measure corporate risk.

- Since the modified Jones model (Dechow et al., 1995) takes into account the impact of accounts receivable, it makes up for the defects of the Jones model and can more effectively measure discretionary accruals [10]. This paper uses the modified Jones model to measure audit quality.

The robustness test results are consistent with the previous research result, proving that the result is robust.

\section{Conclusion}

This article uses big data empirical methods to analyze the impact of over-investment and audit quality on corporate risks, and draws the following conclusions:

Overinvestment in listed companies exacerbates business risks, that is, the deeper the degree of overinvestment of the company, the higher the degree of risk faced by the company, indicating that over-trading is an extremely important factor that causes corporate risks. At the same time, the empirical results of this article show that high-quality external audits restrain the impact of excessive investment on corporate risks. The higher the quality of external auditing, the greater the degree of weakening of the positive correlation between excessive investment and corporate risk. Further grouping research on the nature of property rights found that high-quality external audits in state-owned listed companies can more effectively reduce the impact of excessive investment on corporate risks.

The research conclusions of this paper provide new ideas for mitigating corporate risks in my country's stock market, and looking for new measures to stabilize corporate operations from the perspective of overinvestment and external auditing.

\section{References}

1. Xie Zhong, Kong Lingxiang. Overconfidence, internal control and investment efficiency of executives: Empirical evidence based on data from Chinese A-share listed companies[J]. Industrial Technology Economy, 2018, 37(07): 59-66.

2. Jin L, Myers S. R2 around the world: New theory and new tests[J].Journal of Financial Economics, 2006, 79(2): 257-292. 
3. Jiang Xuanyu, Yi Zhihong. Audit industry expertise and stock price collapse risk[J]. China Accounting Review, 2013, 11(02): 133-150.

4. Chu Yiyun, Cang Yongtao, Yang Yong. Is the followup of financial analysts conducive to the formation of standard audit opinions?-Empirical evidence from the Chinese securities market [J]. Journal of Yunnan University of Finance and Economics, 2017, 33(01): 126-136.

5. Li Wengui, Yu Minggui. The nature of ownership, marketization process and enterprise risk taking[J]. China Industrial Economics, 2012(12): 115-127.

6. Richardson, Scott. 2006. Over-investment of free cash flow, Review of Accounting Studies 11: 159-189.

7. Zhang Hongliang, Wen Ting. Examination and screening of audit quality substitute index validity $[\mathrm{J}]$. Audit Research, 2016(04): 67-75.

8. Jones, Jenneifers. 1991. Earnings Management During Import Relief Investigations, Journal of Accounting Research 29 (2): 193-228.

9. Tang Hua. Can audit quality improve investment efficiency of listed companies [J]. Friends of Accounting, 2019(08): 20-25.

10. Dechow P. M., Sloan R. G., 1995. Detecting Earnings Management. The Accounting Review, 70 (2) :193225. 